Environment Conservation Journal 20 (1\&2) 87-99, 2019

ISSN 0972-3099 (Print) 2278-5124 (Online)

Abstracted and Indexed

\title{
Rainfall probability analysis for conservation of water resources for sustainable irrigation planning
}

Sethi R. R. 凶, Mandal K. G., Behera A., Sarangi A., Aggarwal R. and Ambast S. K.

Received: 29.12 .2018

Revised: 25.02 .2019

Accepted: 24.03.2019

\begin{abstract}
Attempts were made to analyze trends of 44-years (1970-2013) of long-term rainfall using probability distribution functions, seasonal distribution, onset-withdrawal of monsoon, dry and wet spell(s) in 52 standard meteorological weeks (SMW) for Ludhiana (Punjab). Results revealed monsoon season rainfall $(598.5 \mathrm{~mm})$ in 39 rainy days delivers about 79.4 $\%$ of annual rainfall and its effective rainfall was $434.7 \mathrm{~mm}$; pre-monsoon, post-monsoon and winter season contributes 8.2, 7.9 and $4.5 \%$ of annual rainfall. This call for alternate cropping system with low water requiring crops to match with rainfall and distribution, less reliance on irrigation would arrest rapid declining of groundwater.
\end{abstract}

Key words: Irrigation planning, Ludhiana (Punjab), Markov chain model Analysis, Probability analysis, Rainfall analysis, Rice-wheat

\section{Introduction}

India occupies $2.4 \%$ of the world's land area and it supports about $15 \%$ of the world's population. It receives annual precipitation of about $4000 \mathrm{~km}^{3}$ (Kumar et al., 2005); agriculture and allied farming in the country supports $65 \%$ of the population and contributes about $13.9 \%$ to the gross domestic product (DES, 2014; Prasanna, 2014). About 65.26 million ha $(46.3 \%)$ out of 140.80 million ha of net sown area in the country is irrigated (DES, 2014) and remaining area is rainfed $(53.7 \%)$. This rainfall occurs mostly $(\sim 75-80 \%)$ during rainy season due to the influence of south-west monsoon; thus monsoon is often said to be the driver of Indian agriculture (Kumar et al., 2004; Sharma et al., 2010). The rainy season rainfall has direct impact on the agricultural production and is essential for the availability of freshwater for irrigation as well as drinking (Dash et al., 2009; Jain and Kumar, 2012). The study on the climate change and trends in rainfall, its accurate forecasting and contingency planning receives high priority as uncertainty and variability of rainfall affects water resources management (Subash and Sikka, 2014; Subash et al., 2011; Machiwal et al., 2017), agricultural

Author's Address

ICAR-Indian Institute of Water Management, Bhubaneswar751023 , India,

E-mail.: ranurani.prachi@gmail.com production (Bhale et al., 2012; Prasanna, 2014) and overall economy of the country (Khan et al., 2009; Jain and Kumar, 2012). Punjab is one of the north Indian states, which has witnessed the green revolution, rice-wheat cropping system was found as the most important for food self-security in the region (Timsina and Connor, 2001; Hobbs and Gupta, 2003; Gupta and Seth, 2007). In Punjab, rice is grown on 2.61 million ha during rainy season and wheat on 3.41 million ha during winter season, which shares about $40 \%$ of the state gross domestic product and contributes food grains to the central pool (Chahal et al., 2007; Singh and Kaur, 2012). The soils of the region are generally deep alluvium, sandy loam to loam, thus possess high fertility status. Groundwater is a major source of irrigation in the region; but its excessive extraction in Punjab and north Indian states has caused an alarming depletion at a rate of $54 \pm 9 \mathrm{~km}^{3}$ per year between April 2002 and June 2008 (Tiwari et al., 2009), which is equivalent to a net loss of $109 \mathrm{~km}^{3}$ of water during August 2002 to October 2008 (Rodell et al., 2009). The problem of overexploitation of groundwater resources is most severe in central Punjab; the region is also dominated by rice crop during rainy season. While the average annual depletion in groundwater table in the central Punjab was about $17 \mathrm{~cm}$ during the 
1980s and about $25 \mathrm{~cm}$ during the 1990s, it was alarmingly high at $91 \mathrm{~cm}$ per annum during 20002005 (Singh , 2011). Out of 142 blocks in the state, water table is declining in 110 blocks due to overextraction of water than the proportionate recharge. By the year 2023, the water table depth in central Punjab is projected to fall below $21 \mathrm{~m}$ in $66 \%$ area, below $30 \mathrm{~m}$ in $34 \%$ area and below $40 \mathrm{~m}$ in $7 \%$ area (Sidhu et al., 2010). Hence, a study on the rainfall pattern for optimal crop planning and management of rainwater is essential for the region. The probability analysis on long-term rainfall data is useful for agricultural scientists, decision makers, policy planners and researchers for agricultural crop planning and construction of water harvesting structures, irrigation and/ or drainage systems (Singh et al., 2012). Of course, it is essentially required for crop planning and water management under rainfed areas (Sharma et al., 2010; Admasu et al., 2014; Bhelawe et al., 2015). Previously, our attempts were made to analyzing rainfall data of several years for Daspalla region in Odisha, eastern India using probability distribution functions and Markov chain model (Mandal et al., 2015). The same technique was used for analysis of weekly rainfall at Dhera, central rift valley region in Ethiopia (Admasu et al., 2014) and north Lakhimpur, Assam in India (Dabral et al., 2014). It has been evident that probability analyses are more reliable and useful as it delves into more information than a single deterministic forecast (Fritsch, 1998). Information on probability of occurrence of maximum daily rainfall would be useful in devising risk management for sustaining rainfed crop production systems (Mandal and Choudhury, 2015). Long-term weekly, monthly, seasonal and annual rainfall probability helps in better decision making in crop planning, soil and water conservation programme and the optimum utilization of water resources in various production systems (Solanki and Singh, 2009). Markov chain model is used to evaluate the sequence of dry and wet spell(s) for agricultural planning (Pandarinath, 1991; Banik et al., 2002; Panigrahi and Panda, 2002; Srinivasareddy et al., 2008; Fischer et al., 2013). The model output shows the drought proneness of a region and availability of surplus water required for rainwater management (Banik et al., 2002, Kothari et al., 2009; Nema et al., 2013). The Markov model has been proven successful in predicting the average length of wet spells on monthly basis and also used to calculate the return period of wet and dry spells and better suited for paddy cultivation (Sonnadara and Jayewardene, 2015). In our present study, the region belongs to the trans-Gangetic plain in north India; the region is experiencing declining ground water level. Hence, it is hypothesized that the rainfall trend analyses may help in managing rainwater in a systematic way, which can enhance the crop production system in the long run. Rainfall trend analysis showed no significant trend in annual, seasonal and monthly rainfall in most of India (Kumar et al., 2010). Less information is available on the probability analyses and fair idea on the probability of dry and/ or wet spells for Ludhiana, Punjab. Therefore, attempts were made: (1) to study the trends of long-term rainfall of Ludhiana on annual, monthly and weekly basis, and prediction of rainfall at different probability levels, (2) to find out the best-fit probability distribution function for prediction of annual and monsoon season rainfall, (3) for forecasting the onset and withdrawal of monsoon season, (4) for analyzing initial, conditional and consecutive dry and wet spell (s) by using Markov chain model, and (5) for appropriate water and crop management planning for the study region.

\section{Materials and Method \\ Study area and the data}

The study area is the Ludhiana district of Punjab in India. Geographical area of the district is $3790 \mathrm{~km}^{2}$. The soil texture is mostly loamy sand with average sand fraction $78.5 \%$, silt $12.66 \%$ and clay $8.80 \%$ in $0-30 \mathrm{~cm}$ soil depth with average bulk density of $1.44 \mathrm{Mg} \mathrm{m}^{-3}$. Long-term rainfall data were collected for the period of 1970-2013 (44 years) from meteorological station of Punjab Agricultural University, Ludhiana and Punjab. The rainfall data were categorized into four seasons according to Indian Meteorological Department (IMD) such as monsoon (June-September), pre-monsoon (MarchMay), post-monsoon (October-December) and winter (January-February) seasons. Monthly effective rainfall was estimated using FAOCROPWAT 8.0 with the USDA soil conservation service method as stated in Eqs 1 and 2. This method has been used in India by previous 
researchers (Sharma et al., 2010; Mandal et al., 2015).

$\mathrm{P}_{\mathrm{eff}}=\frac{\mathrm{P}(125-0.2 \mathrm{P})}{125} \quad$ for $\mathrm{P}<250 \mathrm{~mm}$

$\mathrm{P}_{\mathrm{eff}}=125+0.1 \mathrm{P} \quad$ for $\mathrm{P} \geq 250 \mathrm{~mm}$

where, $P_{\text {eff }}=$ monthly effective rainfall $(\mathrm{mm})$, and $\mathrm{P}=$ monthly total rainfall $(\mathrm{mm})$

Calculation of probability distribution functions Rainfall probability was analyzed using six probability distribution functions such as normal, two-parameter log normal, three-parameter log normal, Pearson type III, log Pearson type III and Gumbel (maximum and minimum). Different probability distribution functions were estimated as per Mandal et al, 2015. Then Chi-square test as per Kolmogrov-Smirnov (K-S) and Anderson-Darling (A-D) Test were carried out for goodness of fit (Aksoy, 2000; Mohanty et al., 2000; Ebert, 2001; Sharda and Das, 2005; Moore, 2009; Sharma et al., 2010; Singh et al., 2012; Mishra et al., 2013; Bhelawe et al., 2015).

\section{Markov chain model Analysis}

The dry and wet period was decided by the nature of weekly rainfall received. According to the classification by IMD, one whole year was divided into 52 standard meteorological weeks (SMW) and a year started with first SMW $\left(1^{\text {st }}-7^{\text {th }}\right.$ Jan $)$ to $52^{\text {nd }}$ SMW $\left(24^{\text {th }}-31^{\text {st }}\right.$ Dec $)$. The onset and withdrawal and the length of monsoon were the basic parameters for determining crop planning (Punyawardena 2002). Forward accumulation of 75 $\mathrm{mm}$ of rainfall was considered as the onset of monsoon which provides a favourable condition for land preparation and sowing/ planting of rainy season crops and a $20 \mathrm{~mm}$ of accumulated rainfall was considered as withdrawal of monsoon. The withdrawal of monsoon rainfall was determined by the backward summation at the end of monsoon period (Dash and Senapati, 1992; Babu and Lakshminarayana, 1997; Panigrahi and Panda, 2002; Srinivasareddy et al., 2008). The probability of occurrences of rainfall $(p)$ was calculated by using Weibull's method. In this method, the rainfall was arranged in descending order of magnitude, and was given rank 1; next magnitude was given rank 2 and so on. The probability ' $p$ ' of a week having rainfall exceeding or equal to normal was calculated using Weibull's formula as follows.

$$
P=\frac{m}{n+1} \times 100
$$

where, $P=$ probability of occurrence $(\%), m=$ rank number and $n=$ number of years of data used

Markov chain model analysis for computation of probability of occurrences of dry and wet spell

Markov chain model was used for computing probability levels for occurrences of the sequence of dry and wet spell; it was conducted on weekly rainfall data. Less than $20 \mathrm{~mm}$ rainfall in a week was considered as dry week and $20 \mathrm{~mm}$ or more rainfall as wet week (Pandarinath, 1991). The analysis was worked out for initial probabilities, conditional probabilities and consecutive dry and wet week probabilities as per the method described in Mandal et al., 2015.

\section{Results and Discussion}

Monthly and seasonal rainfall trends

Annual rainfall in Ludhiana varies from $379.6 \mathrm{~mm}$ to $1334.0 \mathrm{~mm}$ with an average of $754 \mathrm{~mm}$. Monthly average and effective rainfall showed that highest amount occurred in the month of July (220.2 mm) and it contributes $29.2 \%$ to the annual rainfall; August and September ranked second and third with rainfall of $189.1 \mathrm{~mm}$ and $105.2 \mathrm{~mm}$, respectively and contributes about $25.1 \%$ and 14.0 $\%$ to annual rainfall, respectively. The seasonal rainfall distribution during monsoon, post monsoon, pre-monsoon and winter season showed considerable variation (Table 1). The southwest monsoon which delivers about $79.4 \%$ of annual rainfall i.e., an amount of about $598.5 \mathrm{~mm}$ was received during rainy season; and the effective rainfall was $434.7 \mathrm{~mm}$. The monsoon rainfall was predominant in the region. Winter and postmonsoon contributes about $4.5 \%$ and $7.9 \%$, respectively. Whereas pre-monsoon rainfall contributes $8.2 \%$ to annual rainfall with an average of $61.5 \mathrm{~mm}$ and effective rainfall of $59.5 \mathrm{~mm}$ which was meant for land preparation for rainy season crops. The effective rainfall distribution in the study area was effectively used by the rice-wheat cropping system. 


\section{Prediction of rainfall using probability distribution functions}

Probability of occurrences of monthly rainfall in January through May and October through December was very less even at $50 \%$ level, whereas it was higher in the months, June through September than other months (Table 2). In general, rainfall amount decreases in higher probability levels in every month. Probability of occurrences of seasonal rainfall showed at higher magnitude in monsoon season than post-monsoon, winter and pre-monsoon seasons (Table 3). As the postmonsoon rainfall was very less, its probability was near zero; however during winter and pre-monsoon season, probability of occurrence was also very low in the higher level. Probable annual rainfall was $504.7 \mathrm{~mm}$ at $50 \%$ probability and $107.8 \mathrm{~mm}$ at 90 $\%$ probability.

Six different probability distribution functions viz. normal, two-parameter log normal, three-parameter log normal, Pearson type III, log Pearson type III and Gumbel (maximum and minimum) were fitted for annual rainfall (Fig. 1) and for monsoon rainfall (Fig. 2). The statistic and rank values of different probabilities under Chi-square, K-S and A-D test for annual and monsoon rainfall revealed that Chisquare test showed good statistic than K-S and A-D test for annual and monsoon rainfall (Table 4). Results and trends showed that log Pearson type III is the best-fit probability distribution functions to predict annual rainfall with the rank value of 1 . Similarly, for monsoon rainfall probability distribution function, Chi-square test performed better than the other two tests with its statistic ranged value between 0.78 and 3.51. But in both Chi-square and K-S test, normal distribution function ranked first and is found best-fit function for predicting monsoon rainfall.

Analyses of rainfall for onset and withdrawal of monsoon season

The results on onset, withdrawal, longest monsoon period and shortest monsoon period, based on weekly (SMWs) analyses, reveal that onset of monsoon mostly happens in $28^{\text {th }} \mathrm{SMW}\left(9^{\text {th }}-15^{\text {th }}\right.$ July) and remains active up to $38^{\text {th }} \mathrm{SMW}\left(17^{\text {th }}-23^{\text {th }}\right.$ September) (Table 5). Hence, mean length of rainy season was found to be of 11 weeks. It is also clear that the longest and shortest monsoon period was the $27^{\text {th }}$ SMW $\left(2^{\text {nd }}-8^{\text {th }}\right.$ July $)$ in the year 1986 , and the $30^{\text {th }}$ SMW $\left(23^{\text {rd }}-29^{\text {th }}\right.$ July $)$ in the year 1981 , respectively. In one year i.e., in 1986, the earliest week of onset of monsoon happened in $25^{\text {th }}$ SMW $\left(18^{\text {th }}-24^{\text {th }}\right.$ June) and also the earliest withdrawal in $33^{\text {rd }}$ SMW $\left(13^{\text {th }}-19^{\text {th }}\right.$ August $)$; that was the longest monsoon period of 17 weeks (119 days). Similarly, the shortest monsoon period of 4 weeks (28 days) occurred in 1981 between the SMW $30^{\text {th }}$ and $33^{\text {rd }}$ $\left(13^{\text {th }}-19^{\text {th }}\right.$ August). The most delayed onset and withdrawal occurred in $31^{\text {st }}$ SMW ( $30^{\text {th }}$ July- $5^{\text {th }}$ August) and $43^{\text {rd }}$ SMW (22 $2^{\text {nd }}-28^{\text {th }}$ October $)$, respectively. In terms of probability, $24^{\text {th }}$ through $30^{\text {th }}$ weeks have 29.3 through $92.3 \%$ probability (Table 6); similarly monsoon withdrawal event occurs in $35^{\text {th }}$ SMW ( $27^{\text {th }}$ August $-02^{\text {nd }}$ September $)$ with $24.5 \%$ probability through $42^{\text {nd }} \mathrm{SMW}\left(15^{\text {th }}-\right.$ $21^{\text {st }}$ October) with $97.7 \%$ probability.

\section{Markov chain model}

Result of initial and conditional probabilities for dry and wet weeks were presented in Table 7 for 52 standard meteorological weeks. The result revealed that the probabilities of occurrence of dry spell of one week, $P(D)$ was higher (68.18-90.91\%) up to $25^{\text {th }}$ SMW. Again the probability of occurrences of a dry week followed by another dry week $P(D D)$ and the dry week followed by a wet week $P(D W)$ varies from 57 to $95 \%$ and 71 to $100 \%$, respectively during the duration of $1^{\text {st }}$ to $25^{\text {th }} \mathrm{SMW}$. From $26^{\text {th }}$ SMW the greater probabilities $(>50 \%)$ of occurrence of wet week were observed up to $34^{\text {th }}$ SMW and the percentage probabilities of getting wet period was about 52 to $80 \%$. Hence the probabilities of getting dry week decreases, and $P(D)$ and $P(D D)$ values get lower during the monsoon period. Again, $P(D)$ values were higher that $50 \%$ from $35^{\text {th }}$ SMW onwards, and obviously the $P(W)$ and $P(W W)$ values were lower, even zero in several weeks. The probability of getting wet week preceded by another wet week varied between 49 to $80 \%$. Further the probability of getting dry spell increases after the $42^{\text {nd }}$ SMW to the end of the year $\left(52^{\text {nd }} \mathrm{SMW}\right)$ with the percentage varied from 61 to $100 \%$. The analyses of consecutive dry and wet spells showed that the possibility of occurrences of two consecutive weeks dry i.e., $P(2 D)$ during $1^{\text {st }}$ to $25^{\text {th }}$ SMW was higher with percentage ranging from 39 to $93 \%$ (Table 8). But the chances of getting three consecutive weeks dry i.e., $P(3 D)$ was less and the probability varied from between 7 and $30 \%$ in first 25 weeks of the year; chances of occurrence of consecutive wet weeks 
Rainfall probability analysis for conservation of water resources

Table 1. Rainfall distribution in different seasons in Ludhiana based on 44-years long-term rainfall (19702013)

\begin{tabular}{|l|c|c|c|}
\hline \multicolumn{1}{|c|}{ Seasons } & $\begin{array}{c}\text { Average } \\
\text { rainfall (mm) }\end{array}$ & $\begin{array}{c}\text { Effective rainfall } \\
(\mathbf{m m})\end{array}$ & $\begin{array}{c}\text { of annual } \\
\text { rainfall }\end{array}$ \\
\hline Pre-monsoon (March-May) & 61.5 & 59.5 & 8.2 \\
\hline Monsoon (June-September) & 598.5 & 434.7 & 79.4 \\
\hline Post-monsoon (October-December) & 33.7 & 33.0 & 4.5 \\
\hline Winter (January-February) & 59.7 & 56.8 & 7.9 \\
\hline
\end{tabular}

Table 2. Probability of occurrences of monthly rainfall at different levels

\begin{tabular}{|c|c|c|c|c|c|c|c|c|c|c|c|c|}
\hline $\begin{array}{c}\text { Probability } \\
\text { levels } \\
(\boldsymbol{\%})\end{array}$ & Jan & Feb & Mar & Apr & May & Jun & Jul & Aug & Sep & Oct & Nov & Dec \\
\hline 50 & 15.9 & 20.0 & 13.4 & 7.4 & 9.7 & 49.5 & 178.0 & 149.2 & 54.9 & 0.6 & 0.1 & 5.8 \\
\hline 60 & 9.0 & 16.4 & 9.8 & 5.4 & 4.7 & 43.7 & 145.9 & 123.2 & 41.2 & 0.0 & 0.0 & 2.3 \\
\hline 70 & 4.8 & 10.8 & 4.1 & 2.9 & 1.6 & 37.0 & 112.9 & 104.5 & 27.5 & 0.0 & 0.0 & 0.1 \\
\hline 80 & 2.3 & 3.3 & 1.0 & 1.1 & 0.1 & 30.4 & 89.4 & 71.5 & 19.3 & 0.0 & 0.0 & 0.0 \\
\hline 90 & 0.1 & 0.1 & 0.1 & 0.0 & 0.0 & 18.4 & 38.7 & 48.4 & 1.7 & 0.0 & 0.0 & 0.0 \\
\hline
\end{tabular}

Table 3. Probability of occurrences of seasonal rainfall at different levels

\begin{tabular}{|c|c|c|c|c|c|}
\hline $\begin{array}{c}\text { Probability } \\
\text { levels (\%) }\end{array}$ & $\begin{array}{c}\text { Monsoon } \\
\text { (Jun-Sep) } \\
\mathbf{m m}\end{array}$ & $\begin{array}{c}\text { Post- monsoon } \\
\text { (Oct-Dec) } \\
\mathbf{m m}\end{array}$ & $\begin{array}{c}\text { Winter } \\
\text { (Dec-Feb) } \\
\mathbf{m m}\end{array}$ & $\begin{array}{c}\text { Pre-monsoon } \\
\text { (Mar-May) } \\
\mathbf{m m}\end{array}$ & $\begin{array}{c}\text { Annual } \\
\text { rainfall } \\
\text { mm }\end{array}$ \\
\hline 50 & 431.7 & 0.6 & 41.8 & 30.5 & 504.7 \\
\hline 60 & 354.0 & 0.0 & 27.8 & 20.0 & 401.9 \\
\hline 70 & 282.0 & 0.0 & 15.8 & 8.7 & 306.6 \\
\hline 80 & 210.8 & 0.0 & 5.6 & 2.3 & 218.8 \\
\hline 90 & 107.3 & 0.0 & 0.2 & 0.1 & 107.8 \\
\hline
\end{tabular}


i.e., $P(2 W)$ and $P(3 W)$ are very less in the corresponding weeks. As the arrival of the monsoon from $26^{\text {th }}$ SMW probability of getting two and three consecutive weeks wet increased; and $P(2 W)$ and $P(3 W)$ values were very less or zero in the weeks, $39^{\text {th }}$ SMW through $52^{\text {nd }}$ SMW.

The major cropping system, rice-wheat is followed by the farmers over several years in the study region i.e., within the trans-Gangetic plains of the country, rice during rainy season and wheat in winter. The water requirement of rice in the study area is about $965-1371 \mathrm{~mm}$ depending upon the growing period and varieties (Kaur et al., 2011). Average annual rainfall of the study area i.e., Ludhiana is about $750 \mathrm{~mm}$ which is not sufficient to meet water requirement of rice-wheat cropping system; that is why farmers provide irrigation to rice through extraction of groundwater; overdrafting of ground water resulted in declining of water table, which has become a serious concern. Our analyses indicate that the rainfall received during monsoon season is about $600 \mathrm{~mm}$ i.e., $~ 80$ $\%$ of average annual rainfall. Long term rainfall analysis showed that monsoon and annual rainfall is in decreasing trend where as pre, post and winter rainfall is in increasing trend in India (Kumar et al., 2010). This indicates that rainwater management is very crucial and should get the top priority for the area. For Ludhiana, post-monsoon season and winter season rainfall, if combined, it amounts to $93.4 \mathrm{~mm}$ (Table 1), though almost the total amount is effective rainfall, is not enough to meet the demand. Supplemental irrigation is provided from groundwater source to wheat crop. Further, there is a scope for storage of excess rainfall i.e., $163.8 \mathrm{~mm}$ which occurs during monsoon period in addition to the effective rainfall of 434.7. Of course, there is a possibility of year-to-year variation of this mean rainfall. Another concern is that crops, rice and wheat are high water demanding.

The nature of rainfall amount and distribution call for firstly, the choice of crops and appropriate cropping pattern to fitting the rainfall as well as to arresting groundwater depletion, secondly the use of improved soil-water-crop management technologies as well as water saving irrigation methods. There has been a felt need that water saving technologies be promoted to check groundwater depletion, which may improve also the access of the smallholders to groundwater (Kaur and Vatta, 2015). Now, it is the high time when the farmers of Ludhiana should plan for water-wise methods of rice cultivation which would reduce amount of water inputs. In eastern India, it has been reported that water input for wet land preparation for transplanting of rice was $362-401 \mathrm{~mm}$, whereas for aerobic rice a pre-sowing irrigation was only 54-62 mm (Mandal et al., 2013b); hence, by adopting aerobic method of rice cultivation irrigation requirement may be reduced considerably. Crop diversification is another strategic option for optimal use of water resources. In this rice-wheat growing region, indiscriminate use of groundwater for irrigation would be arrested if low water requiring crops are grown. In a study in eastern India, rice-based diversified systems involving cowpea, sunflower, short duration maize would increase crop water use efficiency with concomitant increase in total system productivity, production efficiency while maintaining soil organic carbon (Mandal et al., 2014). By adopting water conservation techniques like controlled irrigation method, direct-seeded rice and adjustment of sowing and harvesting period would effectively utilize the excess rainwater in the study area during the monsoon season.

It has been tested statistically in our study that the log Pearson type III is the best-fit probability distribution function to predict annual rainfall in Ludhiana. The higher degree of accuracy has been obtained with this prediction function; and it has comparatively better strength to describe the 44 years of rainfall data with least departure of estimated values from the observed and actual rainfall data. Further, our analyses indicate that normal distribution function is the best-fit prediction model for monsoon season rainfall in Ludhiana. The monsoon rainfall in Ludhiana did not vary significantly for 44 years (1970-2013). These have been emerged based on the goodness of fit tests using both parametric as well as nonparametric statistical tests. However, studies have been carried out elsewhere in India where Gumbel distribution was the best-fit prediction function for weekly and monthly maximum rainfall. Bhakar et al., (2008) conducted a statistical analysis on monthly and weekly rainfall for Kota using 35 years daily rainfall data, and they have found the pattern of rainfall consistent during monsoon period. The probability model, thus emerged out 
Rainfall probability analysis for conservation of water resources

Table 4. Chi-square, Kolmogorov-Smirnov (K-S) and Anderson-Darling (A-D) test statistics for each probability distribution function for annual and monsoon season rainfall

\begin{tabular}{|c|c|c|c|c|c|c|}
\hline \multirow{2}{*}{$\begin{array}{c}\text { Probability } \\
\text { distribution functions }\end{array}$} & \multicolumn{3}{|c|}{ Annual } & \multicolumn{3}{|c|}{ Monsoon } \\
\hline & $\begin{array}{c}\text { Chi-square } \\
\text { test }\end{array}$ & K-S test & A-D test & $\begin{array}{c}\text { Chi-square } \\
\text { test }\end{array}$ & K-S test & A-D test \\
\hline Normal & 1.24 & 0.07 & 0.25 & 0.78 & 0.67 & 0.33 \\
\hline $\begin{array}{l}\text { Two-Parameter log } \\
\text { Normal distribution }\end{array}$ & 0.86 & 0.06 & 0.26 & 3.14 & 0.11 & 0.43 \\
\hline $\begin{array}{l}\text { Three-parameter log } \\
\text { normal distribution }\end{array}$ & 0.88 & 0.06 & 0.17 & 3.51 & 0.08 & 0.22 \\
\hline $\begin{array}{l}\text { Pearson type III } \\
\text { distribution }\end{array}$ & 0.88 & 0.05 & 0.17 & 1.28 & 0.08 & 0.22 \\
\hline $\begin{array}{l}\text { Log Pearson type III } \\
\text { distribution }\end{array}$ & 0.79 & 0.05 & 0.16 & 2.77 & 0.76 & 0.22 \\
\hline Gumbel (maximum) & 1.12 & 0.07 & 0.47 & 2.75 & 0.10 & 0.45 \\
\hline Gumbel (minimum) & 2.34 & 0.14 & 1.74 & 2.73 & 0.11 & 1.92 \\
\hline
\end{tabular}

Table 5. Onset and withdrawal weeks (SMW) for monsoon season rainfall, based on long-term data (19702013)

\begin{tabular}{|l|c|c|c|c|}
\hline \multirow{2}{*}{ Particulars } & \multicolumn{2}{|c|}{ Onset week } & \multicolumn{2}{c|}{ Withdrawal week } \\
\cline { 2 - 5 } & $\begin{array}{c}\text { Standard } \\
\text { meteorological } \\
\text { week (SMW) }\end{array}$ & Date/ period & $\begin{array}{c}\text { Standard } \\
\text { meteorological } \\
\text { week (SMW) }\end{array}$ & Date/ period \\
\hline Average & 28 & 09-15 July & 38 & $22-28$ October \\
\hline Longest & 27 & 02-08 July & 43 & $13-19$ August \\
\hline Shortest & 30 & 23-29 July & 33 & $13-19$ August \\
\hline Earliest & 25 & 18-24 June & 33 & $22-28$ October \\
\hline Delayed & 31 & 30 July- 05 August & 43 & \\
\hline
\end{tabular}

Table 6. Probability of onset and withdrawal weeks for monsoon rainfall

\begin{tabular}{|c|c|c|c|}
\hline Onset SMW & $\begin{array}{c}\text { Probability of occurrences } \\
(\%)\end{array}$ & Withdrawal SMW & $\begin{array}{c}\text { Probability of occurrences } \\
(\%)\end{array}$ \\
\hline 24 & 29.3 & 35 & 24.5 \\
\hline 25 & 42.7 & 36 & 50.0 \\
\hline 26 & 56.6 & 37 & 70.0 \\
\hline 27 & 67.1 & 38 & 87.8 \\
\hline 28 & 76.9 & 40 & 95.1 \\
\hline 29 & 88.5 & 42 & 97.7 \\
\hline 30 & 92.3 & 39 & \\
\hline
\end{tabular}


i.e., normal distribution function would be very useful for taking policy decision to go for conservation of excess rainfall in Ludhiana during the monsoon season. Similar model was also used for conservation of surplus rainfall through water harvesting structures during post-monsoon season in Koraput district of Odisha, an eastern Indian state (Panda et al., 2009), they observed no significant difference between observed and predicted values with two-parameter and threeparameter Gamma distribution function. From our study, it is also revealed that only one single probability distribution would not be appropriately used for all the rainfall data sets over years; previous reports indicate different probability models for different regions and seasons (Kumar, 2000, Singh, 2001, Kumar et al., 2007, Singh et al., 2012). Similar inference was drawn by Sharda and Das (2005), that three-parameter distributions were not so significant over two-parameter distribution. As the Gamma distribution function contains more number of parameters than other functions, Sharma et al., (2010), have found log normal distribution as the best-fit model for annual rainfall in Pantnagar, India. Our results are corroborated with the findings of Subudhi (2007), that normal distribution function was the best-fit model for prediction of monsoon rainfall in Chakapada block of Kandhamal district in Odisha. Our analyses reveal that the most probable occurrence and average onset week of monsoon in Ludhiana is in $28^{\text {th }} \mathrm{SMW}\left(9^{\text {th }}-15^{\text {th }}\right.$ July), and it remains active up to $38^{\text {th }}$ SMW ( $17^{\text {th }}$ $23^{\text {th }}$ September) (Table 5 and 6). This indicates that on an average monsoon rainfall is distributed over 11 weeks or about 80 days. Hence, the crop planning is suggested to match with this period. Land preparation should be completed before $28^{\text {th }}$ SMW and the sowing and/ or planting operation is advisable to be completed by $9-15^{\text {th }}$ July. In addition, the soil and water management technologies should be adopted for efficient utilization of rainwater as well as its conservation in-situ and off-situ. The strategic plan for adopting short duration high yielding variety, conservation agriculture technology with reduced or zero tillage, bed planting, direct-seeded in rice (and optimizing crop yield, better water management options can be explored (Abrol, 1999; Hobbs and Gupta, 2003; Gupta and Seth, 2007; Walia et al., 2011; Singh et al., 2013; Timsina and Connor, 2001). Similarly, mean withdrawal week is $38^{\text {th }}$ SMW $\left(17^{\text {th }}-23^{\text {th }}\right.$ September), hence soil moisture conservation towards physiological maturity of crops and effective utilization of residual soil moisture through sowing of succeeding crops immediately after harvest of the first crop would be essential. Conservation tillage or crop residue management and use of no-till seed drill would be useful for the next crop i.e., for winter season crops. Evidences are available that use of appropriate land surface modification and choice of appropriate sole or intercrops utilize rainwater and residual soil moisture efficiently. In central India, broad-bed and furrow land configuration reduces runoff of water and soil loss compared to flat-bed during rainy season, and enhances yield of diversified crops viz. soybean, maize, pigeonpea as sole and as well as intercropping and succeeding chickpea by about 12.7-20.0\% (Mandal et al., 2013a).

The broad-bed and furrow method would avoid water congestion if heavy rainfall occurs, and facilitate soybean-chickpea or intercropping systems. By this way complete reliance on irrigation, as is being followed for rice-wheat cropping in Ludhiana, would be eliminated. Soybean-chickpea, maize-chickpea, soybean-lentil, maize-lentil or soybean-wheat may be effective cropping systems suiting to rainfall trends and pattern in different seasons, onset and withdrawal behaviour. In central Indian situation, which is having the similar rainfall pattern, based on a longterm field experiment on soybean-wheat system, it was concluded that no-tillage and/ or reduced tillage systems with crop residue retention would be a suitable practice for efficient management of rainwater and sustainable crop production (Hati et al., 2014). The probability of occurrence of dry spells is found higher up to $25^{\text {th }} \mathrm{SMW}$, that means soil moisture retention through mulching and light hoeing in inter-row spaces for standing winter crop would be beneficial. Other contingency measures, if required, need to be adopted if the dry spells continues for two weeks. Of course, the amount of excess rainwater $(163.8 \mathrm{~mm})$, which was stored or used to recharge groundwater, may be utilized for irrigation to winter crop(s) as life-saving irrigation in case of prolonged dry spells or during the most critical growth stage of the crop with respect to moisture stress. As the chances of getting three consecutive 


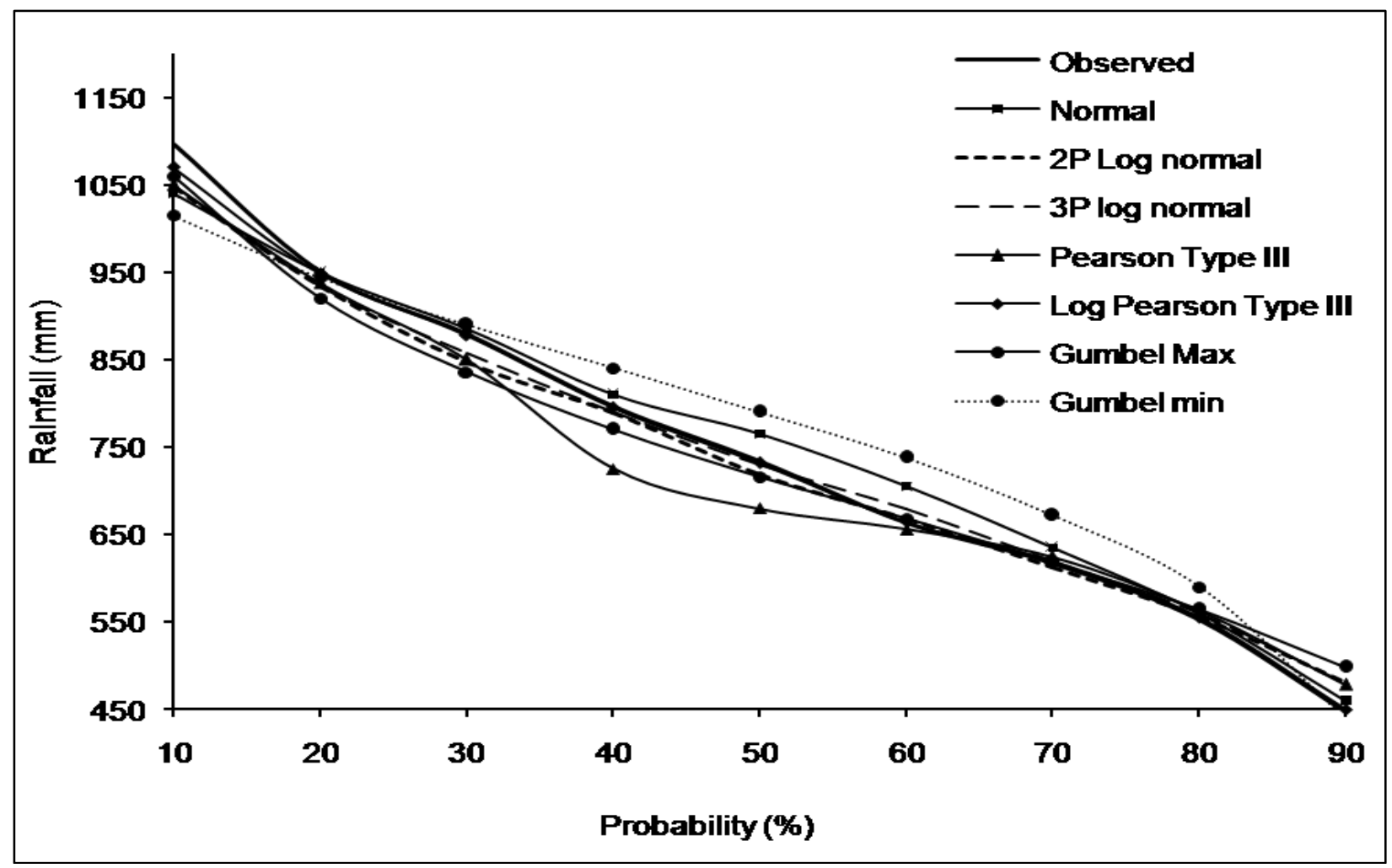

Fig. 1 Observed and predicted annual rainfall in Ludhiana, India using probability distribution functions

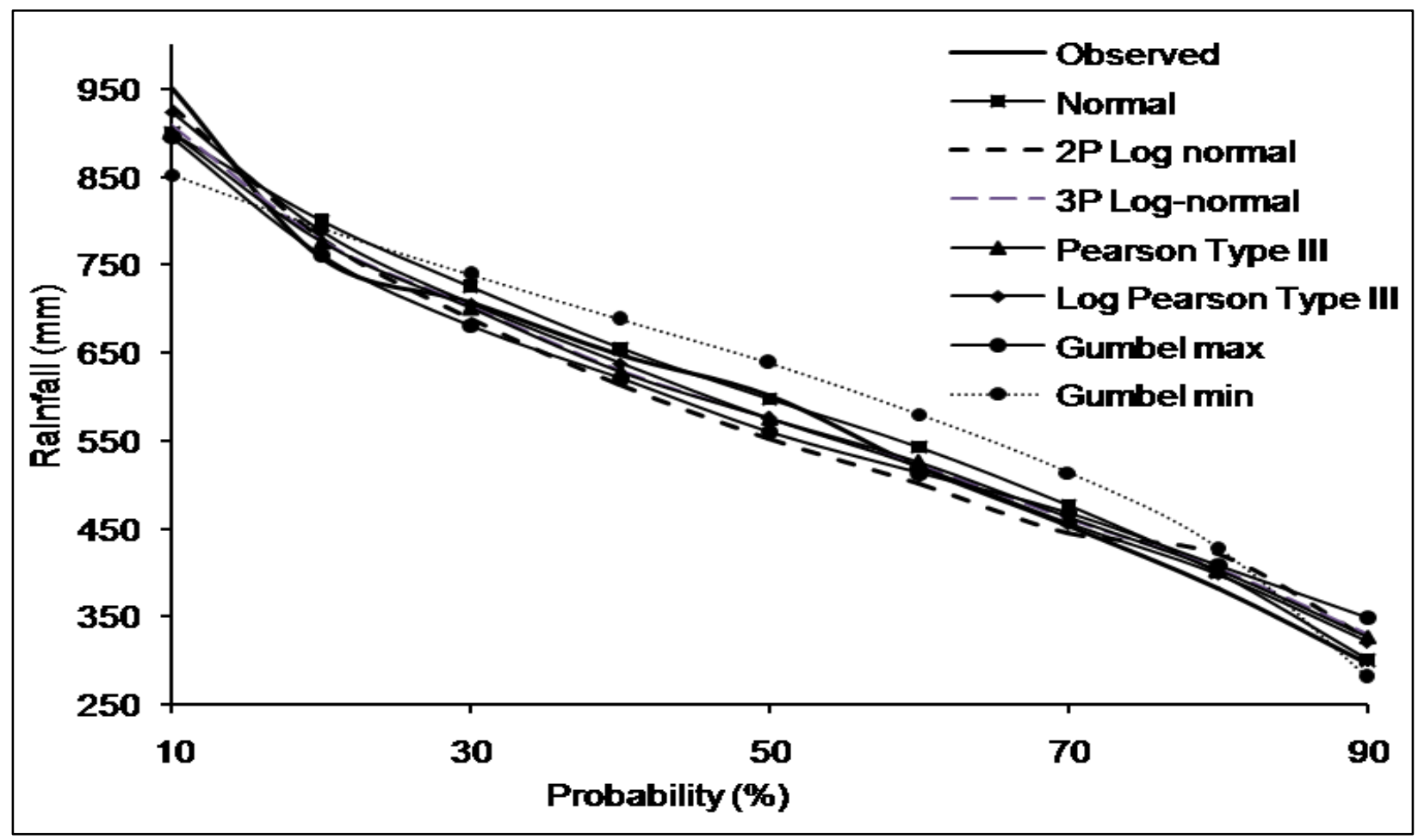

Fig. 2 Observed and predicted monsoon rainfall in Ludhiana, India using probability distribution functions 
weeks dry during monsoon session was less due to some pre-monsoon rainfall and the probability varied from between 7 and $30 \%$ in first 25 weeks of the year; chances of occurrence of consecutive wet weeks are very less in the corresponding weeks. The Markov chain analyses would help in adopting appropriate soil and crop management measures during the dry spells.

\section{Conclusion}

Probability analyses of long-term rainfall, seasonal distribution, onset and withdrawal of monsoon would form the guidelines for suitable crop planning and soil water conservation in Ludhiana, Punjab. Rainfall has been quantified with probability of occurrences; it has been shown that there is scope for storage of excess rainfall (163.8 $\mathrm{mm}$ ) into on-farm reservoir which otherwise is getting lost due to runoff, deep percolation and evaporation. A guideline for systematic recharge of groundwater would be possible tapping this excess rainfall during monsoon months. It is clear that the most important is the monsoon season rainfall; hence our analyses have indicated its most probable onset and withdrawal of effective monsoon. Now, appropriate cropping pattern, land preparation and all agricultural operations could be planned in advance. It is concluded from our analyses that the log Pearson type III and normal distribution would be useful for prediction of annual rainfall and monsoon rainfall, respectively. Rice-wheat is the cropping system, which is mostly followed by Ludhiana farmers; but this system is not suggested for long-term sustainability; rather alternate cropping systems viz. soybean-chickpea, maizechickpea, soybean-lentil, maize-lentil or other systems which would require less amount of water in addition to rainfall received. Since, postmonsoon rainfall is more uncertain and erratic than monsoon rainfall, growing of high value postmonsoon crops without supplementary irrigation would be risky. By this way, irrigation requirement will be decreased; a balance of groundwater resources with its minimal extraction during monsoon season and promoting the groundwater recharge could be maintained. If rice is grown, then short duration, high yielding and moisture stress tolerant cultivars may be chosen than long duration; the cultivation techniques like aerobic method or the direct dry-seeding is suggested to reduce the water required for puddling. Dry-seeding of rice or sowing/ planting or other crop is advisable to be completed by $28^{\text {th }}$ SMW (9-15 $5^{\text {th }}$ July). The soil and crop management technologies like broad-bed and furrow method, mulching during the terminal drought, if occurs, crop residue retention and conservation tillage for soil moisture conservation may be adopted. Markov chain model analyses has highlighted the knowledge on probability of dry and wet spells; it has helped to find out the possibilities of getting dry spells during the crop period in Ludhiana. It would be easier for growers to take appropriate contingency measures, if dry spells occur during early part of the year which coincide with winter cropping period. Overall, rainfed cropping system could be planned based on this rainfall analyses so that effective utilization of rainwater is achieved, and indiscriminate use of groundwater is reduced. A better soil-water-crop management would be possible for sustainable agriculture in the region.

\section{Acknowledgement}

Authors thank National Agricultural Science Fund (NASF) of Indian Council of Agricultural Research for providing financial support for pursuing this research under the project titled "Decision Support System for Enhancing Water Productivity of Irrigated Rice-Wheat Cropping System".

\section{References}

Admasu, W., Tadesse, K., Yemenu, F. and Abdulkadir, B. 2014. Markov chain analysis of dry, wet weeks and statistical analysis of weekly rainfall for agricultural planning at Dhera, central rift valley region of Ethiopia. African J Agric. Res., 9(29): 2205-2213.

Aksoy, H., 2000. Use of gamma distribution in hydrological analysis. Turk J Engg Env Sci., 24: 419-428.

Babu, P. N., Lakshminarayana, P., 1997. Rainfall analysis of dry land watershed-Polkepad: a case study. J Indian Water Res Soc, 17:34-38.

Banikm, P., Mandal, A., Sayedur, R. M. 2002. Markov chain analysis of weekly rainfall data in determining droughtproneness. Discret Dyn Nat Soc, 7: 231-239.

Bhakar, S. R., Mohammed, I., Devanda, M., Chhajed, N., Bansal, A. K. 2008. Probability analysis of rainfall at Kota. Indian J Agric Res, 42(3): 201 -206. 


\section{Rainfall probability analysis for conservation of water resources}

Bhale, V. M., Tupe, A. R., Karmore, J. V. and Kale, M. A. 2012. Crop planning in relation to climate change in rain fed regions. J Agric Technol, 8(2): 443-452.

Bhelawe, S., Manikandan, N., Khavse, R., Chaudhary, J. L., Patel, S. R. 2015. Analysis of rainfall probabilities for strategic crop planning in Raipur district of Chhattisgarh state. Curr World Environ, 10(1): 253-257.

Chahal, G. B. S., Sood, A., Jalota, S. K., Choudhury, B. U., Sharma, P. K. 2007. Yield, evapotranspiration and water productivity of rice (Oryza sativa L.)-wheat (Tritium aestivum L.) system in Punjab (India) as influenced by transplanting date of rice and weather parameters, Agric Water Manag, 88(1-3): 14-22.

Dabral, P. P., Purkayastha, K., Aram, M. 2014. Dry and wet spell probability by Markov chain model- a case study of north Lakhimpur (Assam) India. Int J Agric Biol Engg, 7(6): 8-13.

Dash, M. K. and Senapati, P.C. 1992. Forecasting of dry and wet spell at Bhubaneswar for agricultural planning. Indian J Soil Cons, 10(2): 75-82.

Dash, S. K., Kulkarni, M. A., Mohanty, U. C. and Prasad, K. 2009. Changes in the characteristics of rain events in India. J geophysical Res, 114(10).doi 10.1029/2008JD010572

DES, 2014. Agricultural Statistics at a Glance , 2014. Directorate of Economics and Statistics, Department of Agriculture and Cooperation, Ministry of Agriculture, Government of India. Oxford University Press, New Delhi, pp 32 \& 304-305.

Ebert, E. E. 2001. Ability of a poor man's ensemble to predict the probability and distribution of precipitation. Mon Weather Rev 129: 2461-2480.

Fischer, B. M. C., Mul, M. L. and Savenije, H. H. G. 2013. Determining spatial variability of dry spells: a Markovbased method, applied to the Makanya catchment, Tanzania. Hydrol Earth Syst Sci, 17: 2161-2170.

Fritsch, J. M. 1998. Quantitative precipitation forecasting: report of the eighth prospectus development team, U.S. weather research program. American Met Soc, 79: 285299.

Gupta, R. and Seth, A. 2007. A review of resource conserving technologies for sustainable management of the rice-wheat cropping systems of the Indo-Gangetic plains (IGP). Crop Prot, 26: 436-447.

Hati, K. M., Chaudhary, R. S., Mandal, K. G., Bandyopadhyay, K. K., Singh, R. K., Sinha, N. K., Mohanty, M., Somasundaram, J. and Saha, R. 2014. Effects of tillage, residue and fertilizer nitrogen on crop yields, and soil physical properties under soybean-wheat rotation in vertisols of central India. Agric Res, DOI 10.1007/s40003014-0141-7.
Hobbs, P. R. and Gupta, R. K. 2003. Rice-wheat cropping systems in the Indo- Gangetic plains: Issues of water productivity in relation to new resource conserving technologies. CAB International 2003: 239-253.

Jain, S. K. and Kumar V. 2012. Trend analysis of rainfall and temperature data for India. Curr Sci, 102 (1): 37-49.

Kaur, P., Singh, H., Bal, S. K., Sandhu, S. S. and Singh, A. 2011. Quantitative evaluation of weather variability and rice yields in Punjab- A case study. J Res Punjab Agric Univ, 48: 5-15.

Kaur, S. and Vatta, K. 2015. Groundwater depletion in central Punjab: pattern, access and adaptations, $\mathbf{C u r r} \boldsymbol{S c i}, 108(4)$ : 485-490.

Khan, S. A., Kumar, S., Hussain, M. Z. and Kalra, N. 2009. Climate change, climate variability and Indian agriculture: impacts vulnerability and adaptation strategies. Climate Change and Crops, Environ Sci Engg: 19-39.

Kothari, A. K., Jain, P. M. and Kumar, V. 2009. Analysis of weekly rainfall data using onset of monsoon approach for micro level crop planning. Indian J Soil Cons, 37 (3): 164171.

Kumar, A. 2000. Prediction of annual maximum daily rainfall of Ranichauri (Tehri Garhwal) based on probability analysis. Indian J Soil Cons, 28: 178- 180.

Kumar, A., Kaushal, K. K. and Singh R. D. 2007. Prediction of annual maximum daily rainfall of Almora based on probability analysis. Indian J Soil Cons, 35: 82-83.

Kumar, K. K., Kumar, K. R., Ashrit, R. G., Deshpande, N. R. and Hansen, J. W. 2004. Climate impacts on Indian Agriculture. Int J Climatl, 24: 1375-1393.

Kumar, R., Singh, R. D. and Sharma, K. D. 2005. Water resources of India. Curr Sci, 89 (5): 794-811.

Kumar, V., Jain, S. K. and Singh, Y. 2010. Analysis of longterm rainfall trends in India. Hydrological Sciences Journal 55 (4): 484-496.

Machiwal, D., Dayal, D. and Kumar, S. 2017. Long-term rainfall trends and change points in hot and cold arid regions of India. Hydrological Sciences Journal, 62 (7): 1050-1066.

Mandal, K. G., Hati, K. M., Misra, A. K., Bandyopadhyay, K. K. and Tripathi, A. K. 2013a. Land surface modification and crop diversification for enhancing productivity of a vertisol. International J Plant Production, 7 (3): 455-472.

Mandal, K. G., Kannan, K., Thakur, A. K., Kundu, D. K., Brahmanand, P. S. and Kumar, A. 2014. Performance of rice systems, irrigation and organic carbon storage. Cereal Research Communications, 42 (2): 346-358. 


\section{Sethi et al.,}

Mandal, K. G., Kundu, D. K., Thakur, A. K., Kannan, K., Brahmanand, P. S. and Kumar, A. 2013b. Aerobic rice response to irrigation regimes and fertilizer nitrogen rates. J Food Agric Environ, 11 (3\&4): 1148-1153.

Mandal, K. G., Padhi, J., Kumar, A., Ghosh, S., Panda, D. K., Mohanty, R. K., and Raychaudhuri, M., 2015. Analyses of rainfall using probability distribution and Markov chain models for crop planning in Daspalla region in Odisha, India. Theor Appl Climatol, 121: 517-528.

Mandal, S., Choudhury, B. U. 2015. Estimation and prediction of maximum daily rainfall at Sagar Island using best fit probability models. Theor Appl Climatol, 121: 87-97.

Mishra, P. K., Khare, D., Mondal, A., Kundu, S. and Shukla, R. 2013. Statistical and probability analysis of rainfall for crop planning in a canal command. Agric Sustainable Development, 1(1): 95-102.

Mohanty, S., Marathe R. A. and Singh S. 2000. Probability models for prediction of annual maximum daily rainfall for Nagpur. J Soil Water Conserv, 44(1-2): 38-40.

Moore, R. J. 2009. The probability-distributed principle and runoff production at point and basin scales. Hydrolog Sci J 30(2): 273-297.

Nema, A. K., Bisen, Y., Singh, S. R. and Singh, T. 2013. Markov chain approach - dry and wet spell rainfall probabilities in planning rainfed rice based production system. Indian J Dryland Agric Res Dev, 28(2): 16-20.

Panda, R. K., Naik, B. S., Gore, K. P., Mishra, P. K., Jakhar, P. and Gowda, H. 2009. Use of probability distribution models in rainfall analysis for post monsoon crop planning in Eastern ghat region of Orissa. Indian J Dryland Agric Res Dev 24(1): 75-80.

Pandarinath, N. 1991. Markov chain model probability of dry and wet weeks during monsoon periods over Andhra Pradesh. Mausam, 42(4): 393-400.

Panigrahi, B. and Panda, S. N. 2002. Dry spell probability by Markov chain model and its application to crop planning in Kharagpur. Indian J Soil Cons, 30(1): 95-100.

Prasanna, V. 2014. Impact of monsoon rainfall on the total food grain yield over India. J Earth Syst Sci, 123(5): 1129. 1145 .

Punyawardena, B. V. R. 2002. Identification of the potential of growing seasons by the onset of seasonal rains: A study in the DL1 region of the North Central dry zone. J National Sci Foundation Sri Lanka 30(1\&2): 13-21.

Rodell, M., Velicogna, I. and Famiglietti, J. S. 2009. Satellitebased estimates of groundwater depletion in India. Nature, 460 (7258): 999. doi:10.1038/nature08238
Sharda, V. N., Das, P. K. 2005. Modeling weekly rainfall data for crop planning in a sub-humid climate of India. Agric Water Manage, 76: 120-138.

Sharma, B. R., Rao, K. V., Vittal, K. P. R., Ramakrishna. Y. S., Amarasinghe. U. 2010. Estimating the potential of rainfed agriculture in India: prospects for water productivity improvements. Agric Water Manage 97(1): 23-30.

Sidhu, R. S., Vatta, K. and Dhaliwal, H. S. 2010. Conservation agriculture in Punjab - economic implications of technologies and practices. Indian J Agric Econ, 65: 413427.

Singh, A. and Kaur J. 2012. Impact of conservation tillage on soil properties in rice-wheat cropping system. Agric Sci Res J, 2(1): 30-41.

Singh, B., Rajpurohit, D., Vasishth, A. and Singh, J. 2012. Probability analysis for estimation of annual one day maximum rainfall of Jhalarapatan area of Rajasthan, India. Plant Arch, 12(2): 1093-1100.

Singh, G., Kumar, R., Mishra, C. D., Srikant, M. S., De, N., 2013. Precipitation management under rice based rainfed cropping system: a case study for transect 4 of IndoGangetic plain. Int J Agronomy Plant Production, 4 (S): 3782-3790.

Singh, K. 2011. Groundwater depletion in Punjab: measurement and countering strategies. Indian J Agric Econ, 66: 583-589.

Singh, R. K. 2001. Probability analysis for prediction of annual maximum rainfall of eastern Himalaya (Sikkim mid hills). Indian J Soil Cons, 29: 263-265.

Solanki, N. S. and Singh, A. K. 2009. Rainfall analysis for crop planning in the humid southern plains of Rajasthan. $\boldsymbol{J}$ Water Manage, 17 (2): 81-86.

Sonnadara, D. U. J. and Jayewardene, D. R. 2015. A Markov chain probability model to describe wet and dry patterns of weather at Colombo. Theor Appl Climatol, 119: 333-340.

Srinivasareddy, G. V., Bhaskar, S. R., Purohit, R. C., Chittora, A. K. 2008. Markov chain model probability of dry, wet weeks and statistical analysis of weekly rainfall for agricultural planning at Bangalore. Karnataka J Agric Sci, 21(1): $12-16$.

Subash, N. and Sikka, A. K. 2014. Trend analysis of rainfall and temperature and its relationship over India. Theor Appl Climato, l 117: 449-462.

Subash, N., Ram, M.H.S. and Sikka, A. K. 2011. Decadal frequency and trends of extreme excess/deficit rainfall during monsoon season over different meteorological subdivisions of India. Hydrological Sciences Journal, 56 (7): 1090-1109. 
Subudhi, R. 2007. Probability analysis for prediction of annual maximum daily rainfall of Chakapada block of Kandhamal district in Orissa. Indian J Soil Cons, 35:84-85.

Timsina, J. and Connor, D. J. 2001. Productivity and management of rice-wheat cropping systems: issues and challenges. Field Crop Res, 69: 93-132.
Tiwari, V. M., Wahr, J. and Swenson, S., 2009. Dwindling groundwater resources in northern India, from satellite gravity observations. Geophys Res Lett, 36, L18401. doi:10.1029/2009 GL039401

Walia, S. S., Gill, M. S., Bhushan, B., Phutela, R. P., Bhushan, A.R. P. 2011. Alternate cropping systems to rice (Oryza sativa)-wheat (Triticum aestivum) for Punjab. Indian $\boldsymbol{J}$ Agron, 56(1): 20-27 